\title{
Macrothink

\section{Effect of Aeration on the Rate of Biochemical Oxygen Demand (BOD) in Floating Net Cages in Ir. H Djuanda Reservoir, West Java, Indonesia}

\author{
Lismining Pujiyani Astuti \\ Student at post graduate Water Resources Management, Bogor Agricultural Institute \\ Enan M Adiwilaga \\ Lecture at Fisheries and Marine Science Faculty, Bogor Agricultural Institute \\ Budi Indra Setiawan \\ Lecture at Agricultural Technology Faculty, Bogor Agricultural Institute \\ Niken TM Pratiwi \\ Lecture at Fisheries and Marine Science Faculty, Bogor Agricultural Institute
}

Received: July 27, 2014 Accepted: August 17, $2014 \quad$ Published: August 18, 2014

Doi: 10.5296/jab.v2i2.6160 URL: http://dx.doi.org/10.5296/jab.v2i2.6160

\begin{abstract}
Aeration is an effort to improve dissolved oxygen when oxygen is in critical condition in water body. Ir . H. Djuanda Reservoir is utilized for fish farming activities by floating net cage culture impact on water quality, among others, an increasing of organic matter from the rest of wasted feed and fish feces and decreased oxygen waters. Increasing the organic matter will cause pollution if not balanced with sufficient oxygen to decompose the organic matter. The purpose of this study to determine the rate of BOD $(k)$ in the treatment of water pre and post aerated for 8 hours. The study was conducted in floating net cage culture locations with aeration at a depth of $3.6 \mathrm{~m}$ (depth of hypoxia) with system pumps air through compressor with pressure about 3 atm for 8 hours . Sample was conducted in June - September 2013 and BOD subsequently measured daily for 7 days. $k$ values was calculated by Least Square method. The results showed that the $\mathrm{BOD}_{5}$ was higher in pre- aeration $(4.57-8.74 \mathrm{mg} / \mathrm{l})$ than
\end{abstract}




\section{Macrothink}

Journal of Applied Biotechnology ISSN 2327-0640 2014, Vol. 2, No. 2

post aeration $(3.52$ to $8.13 \mathrm{mg} / \mathrm{l})$. The rate of BOD was higher post- aeration $(0.2461$ to 0.3335 per day) compared to pre- aeration (from 0.1262 to 0.2776 per day). This was caused post aeration oxygen supply gets larger than pre aeration so as to decompose organic matter.

Keyword : aeration, $k$ value, BOD, Ir. H. Djuanda Reservoir 


\section{Introduction}

Aeration is an effort to increase the dissolved oxygen that can be carried out during the critical dissolved oxygen conditions in order to prevent the occurrence of fish mortality (Qoyyum et al., 2005). Endo et al. (2008) states that if the low-oxygen conditions can affect the activity feed, feed conversion, growth and health of farmed fish. Oxygen is a key factor for aquatic life to respiration process. Oxygen is also used for the decomposition of organic matter that can produce compounds that are not harmful to aquatic biota.

The content of organic matter in an amount sufficient to fertilize the waters, but if the more can pollute waters so can decreased dissolved oxygen levels, rising $\mathrm{CO}_{2}$ levels and turbidity (Cahyono, 2001). One source of organic matter in Ir. H. Djuanda reservoir is a waste of fish farming activities in floating net cage which may from residual undigested feed, fish feces and urine. The number of cages in the reservoir has increased from year to year and by 2010 had reached 19630 unit whereas by SK Bupati Purwakarta No. 06 Year 2000, the optimum floating net cage are 2100. This means that the number of unit have over nine times more than the permitted capacity. An increase in organic matter can cause a decreasing of dissolved oxygen because oxygen will be used to the decomposition process of organic matter.

Increasing of organic matter needs to be balanced with sufficient oxygen production. Organic matter in the waters will be decomposed by microbes and requires oxygen. Continuously of oxygen usage for oxidation process leads decreasing of oxygen in the waters. It is supply adequate of oxygen continuously. If the oxygen production is smaller than e oxygen consumption will cause oxygen deficit.

Biochemical Oxygen Demand (BOD) is the amount of oxygen required by microorganisms to decompose organic matter. $\mathrm{BOD}$ value is influenced by temperature, $\mathrm{pH}$, incubation time, osmotic conditions, as well as the oxygen availability (Dhage et al., 2012). Value of $k$ (rate of BOD) shows the magnitude of the rate of decomposition of organic matter by aerobic microorganisms in aquatic and the value $k$ of aerobic conditions is 1/day (Astono et al., 2008; Harsono, 2010). Ultimate BOD is the total amount of oxygen consumed during the reaction (Dhage et al., 2012). The purpose of this study was to determine the value of $\mathrm{k}$ by pre and post aerated treatment for 8 hours in floating net cage water .

\section{Methodology}

The study was conducted at fish farmed by floating net cage in the reservoir Ir. H. Djuanda, West Java in June - August 2013. Aeration was done for 8 hours with air compressed system at a depth of $3.6 \mathrm{~m}$ which is the depth of hypoxia using compressor $2 \mathrm{HP}$ and pressure of 3 atm. Water samples pre and post aeration was taken 3 liters in depth 3,6 m. Then, sample put into dark bottles Winkler respectively of 8 samples to BOD analysis. One sample was analyzed as $\mathrm{DO}_{0 \text { day }}$ (DO initial) and seven bottles was incubated for 7 days as did Singh (2004) in an incubator with temperature as in the location of floating net cage. Observations DO (dissolved oxygen) with the Winkler method (APHA, 2005) carried out every day.

Determination of the rate of oxidation of organic matter $(k)$ through the measurement of BOD every day. To measure the first BOD measuring initial DO (0 day) and then another sample 


\section{IIMacrothink

and dark bottles were incubated and measured daily DO it. BOD value calculation is:

$$
\mathrm{BOD}_{\mathrm{t}}=\left[\mathrm{DO}_{\mathbf{0} \text { day }}-\mathrm{DO}_{\mathrm{t}}\right]
$$

To determine the value of the rate of oxidation of organic matter $(k)$ based on observations of daily BOD by Least Square method (Tchobanoglous et al., 2003; Singh, 2004), namely:

$$
\mathbf{d L} / \mathbf{d t}=-\mathbf{k L}_{\mathrm{t}}
$$

where:

$\mathrm{L}_{\mathrm{t}}=\mathrm{L}_{0}-\mathrm{y}_{\mathrm{t}}$

$\mathrm{y}_{\mathrm{t}}=\mathrm{BOD}_{\mathrm{t}}$

$\mathrm{dy} / \mathrm{dt}=\mathrm{k}\left(\mathrm{L}_{0}-\mathrm{y}_{\mathrm{t}}\right)$

$\mathrm{dy} / \mathrm{dt}=\mathrm{kL}_{0}-\mathrm{ky}_{\mathrm{t}}$

Determination of $k$ and $\mathrm{L}_{0}$ based on linear equations that can be calculated:

$\mathbf{S}_{\mathbf{x}}=\mathbf{n} \sum \mathbf{y}_{\mathbf{t}}{ }^{2}-\left(\sum \mathbf{y}\right)^{2}$

$S_{x y}=n \sum y_{t}(d y / d t)-\left(\sum y_{t}\right)\left(\sum d y / d t\right)$

Slope or $\left.-\mathbf{k}=\mathbf{S}_{\mathrm{xy}} / \mathbf{S}_{\mathbf{x x}}\right)$

Intercept or $\mathbf{k L}_{\mathbf{0}}=\sum(\mathbf{d y} / \mathbf{d t}) / \mathbf{n}+\mathbf{k} \sum\left(\mathbf{y}_{\mathbf{t}}\right) / \mathbf{n}$

$\mathbf{L}_{0}=$ Intercept $/$ (-slope)

$\mathbf{d y} / \mathbf{d t}=\left(\mathbf{y}_{\mathrm{t}+1}-\mathbf{y}_{\mathrm{t}-1}\right) / 2 \Delta t$

where,

$\mathrm{y}_{\mathrm{t}} \quad$ : BOD values observed

$\mathrm{y}_{0} \quad$ : initial BOD or day 0 of $0 \mathrm{mg} / 4$

$\Delta \mathrm{t} \quad$ : time interval of observation

t $:$ observation days $1,2,3, \ldots$

$\mathrm{L}_{0} \quad$ : ultimate BOD (mg/l)

n : total number of observations

$\mathrm{k}$ : The rate of BOD (per day) 
So it can be made the observation table :

\begin{tabular}{|c|c|c|c|c|}
\hline Day & $y_{t}$ & $\mathrm{dy} / \mathrm{dt}$ & $\mathrm{y}_{\mathrm{t}}^{2}$ & $\mathrm{y}_{\mathrm{t}} \cdot \mathrm{dy} / \mathrm{dt}$ \\
\hline 0 & & & & \\
\hline 1 & & & & \\
\hline 2 & & & & \\
\hline 3 & & & & \\
\hline 4 & & & & \\
\hline 5 & & & & \\
\hline 6 & & & & \\
\hline 7 & & & & \\
\hline Total & & & & \\
\hline
\end{tabular}

Furthermore, $k$ values pre and post aeration were analyzed by ANOVA test.

\section{Results and Discussion}

Temperature in depth $3,6 \mathrm{~m}$ in this research used incubation were $29.5 ; 29.5 ; 28.5$ and 28.5 respectively. Changes of BOD pre and post aeration is presented in Figure 1. 
Pre aeration

1

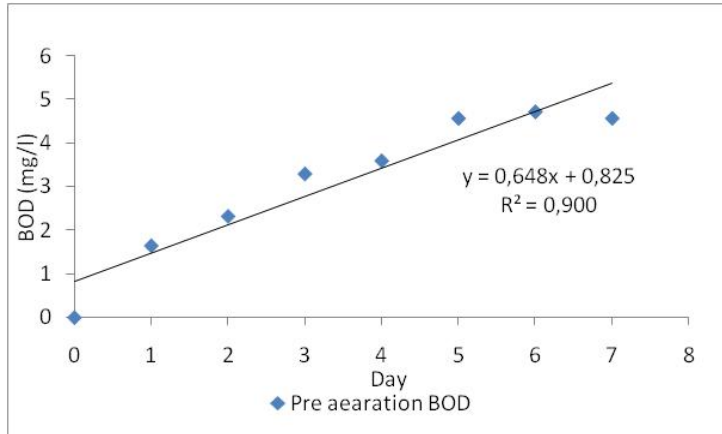

2

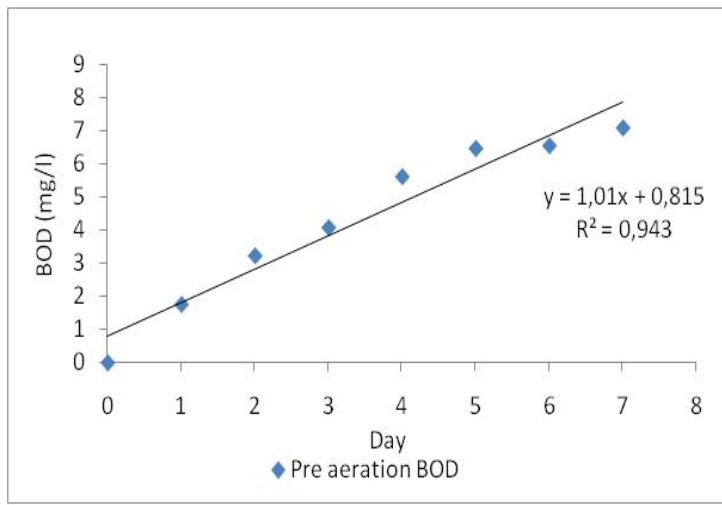

3

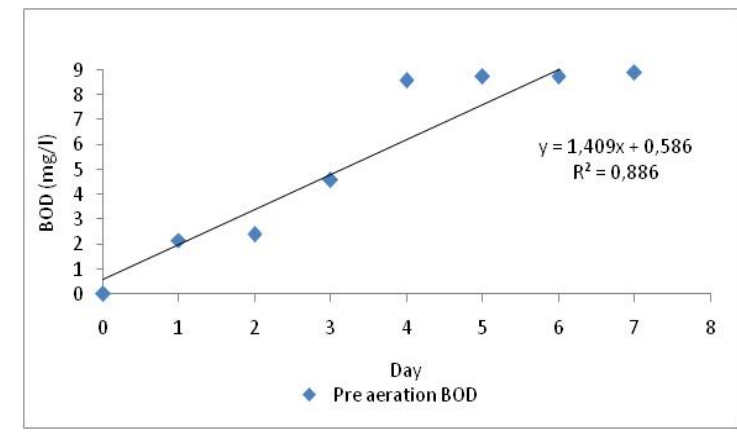

4

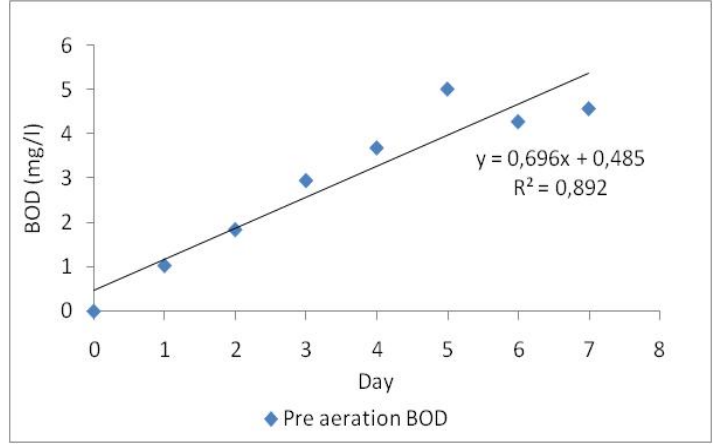

Post aeration

1

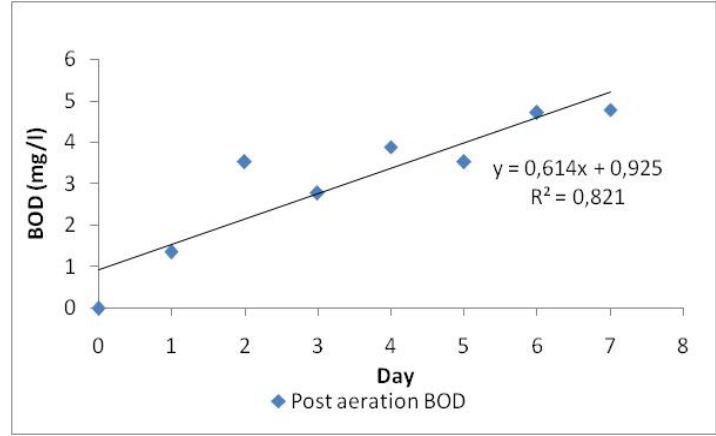

2

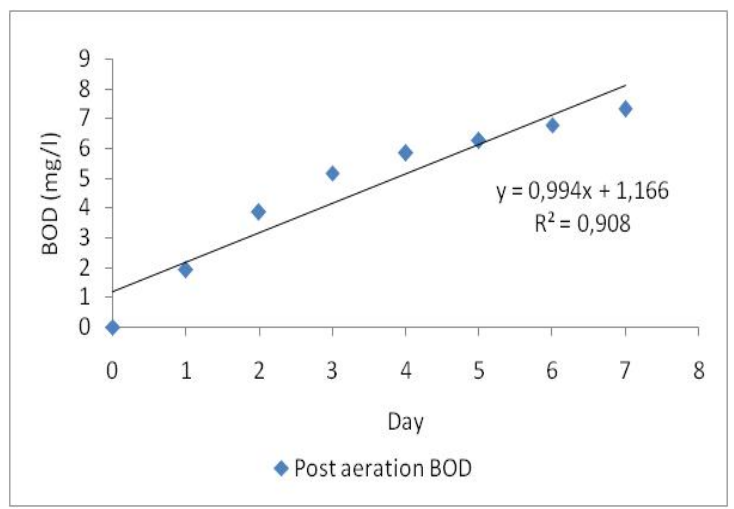

3

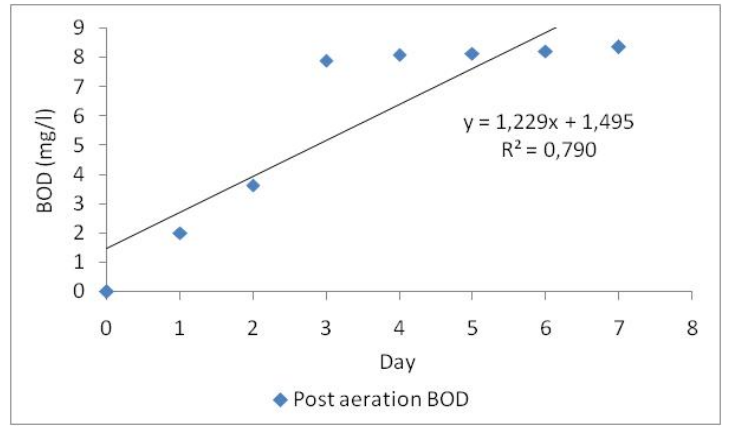

4

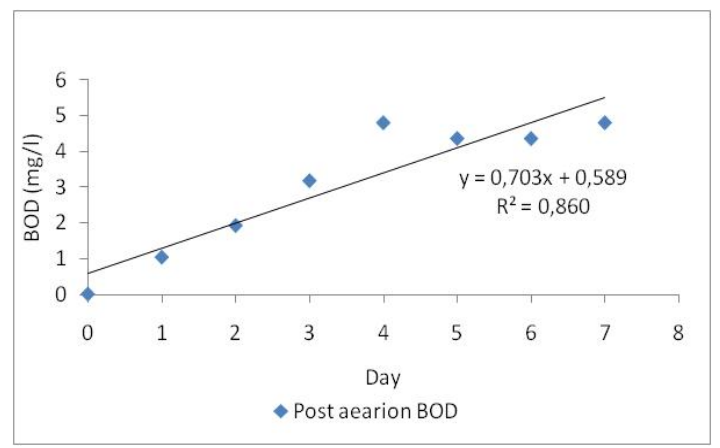

Figure 1. Changes in the amount of BOD during the 7 days of observation 
Based on the relationship of BOD and the incubation time both pre and post aeration showed a close relationship is indicated by the value of $\mathrm{R}$ close to 1 (Figure 1). Increasing of BOD pre aeration is faster than post aeration. It shows that aeration can increase oxygen so as to slow down the increase in BOD due partly decomposed organic matter, while pre aerated having a lower oxygen that has not been able to partially decomposed organic matter due insufficient availability of oxygen. BOD values are lower in the post-aerated water indicates that a process of aerobic decomposition of organic matter (Romayanto et al., 2006).

The results of Sulihingtyas et al. (2010) research showed that the aerated wastewater BOD lower than before aeration. BOD waste water before aeration reaches $83.88 \mathrm{mg} / \mathrm{l}$ and after aerated for 3 days in a row fell to $37.28 \mathrm{mg} / 1$ or approximately decline about $55.56 \%$. BOD 5 in this study are pre-aeration ranging from 4.57 to $8.74 \mathrm{mg} / \mathrm{l}$ and post aeration ranged from 3.52 to $8.13 \mathrm{mg} / \mathrm{l}$ (Table 1). Selvamurugan et al. (2010) study's showed that the coffee wastewater treatment aeration tanks then there reduce of BOD if performed optimally aerated continuously ( 24 hours) for 8 days. The decrease BOD faster with continuous aeration ( 24 hours) which is about $74.5 \%$ compared are intermittent aeration which is about 38-63\%. According Anwari et al., (2011) stated that the longer the time of aeration, the smaller the value of BOD. Aeration can increase dissolved oxygen thereby increasing the activity of microorganisms as decomposers of organic matter decreases as a result of BOD (Santoso, 2010; Selvamurugan et al., 2010).

Table 1. Pre and post aeration of $\mathrm{BOD}_{5}, k$ and Lo value

\begin{tabular}{lllllllll}
\hline \multirow{2}{*}{ Parameters } & $\begin{array}{l}1 \\
\text { Pre } \\
\text { aeration }\end{array}$ & $\begin{array}{l}\text { Post } \\
\text { aeration }\end{array}$ & $\begin{array}{l}\text { Pre } \\
\text { aeration }\end{array}$ & $\begin{array}{l}\text { Post } \\
\text { aeration }\end{array}$ & $\begin{array}{l}\text { Pre } \\
\text { aeration }\end{array}$ & $\begin{array}{l}\text { Post } \\
\text { aeration }\end{array}$ & $\begin{array}{l}\text { Pre } \\
\text { aeration }\end{array}$ & $\begin{array}{l}\text { Post } \\
\text { aeration }\end{array}$ \\
\hline $\begin{array}{l}\mathrm{BOD}_{5} \\
(\mathrm{mg} / \mathrm{l})\end{array}$ & 4,58 & 3,53 & 6,47 & 6,26 & 8,74 & 8,14 & 5,02 & 4,32 \\
$k($ per day) & 0,2776 & 0,3270 & 0,2271 & 0,3335 & 0,1262 & 0,3077 & 0,2195 & 0,2461 \\
Lo (mg/l) & 5,66 & 5,38 & 8,98 & 8,03 & 16,11 & 10,28 & 6,10 & 6,02 \\
\hline
\end{tabular}

$k$ : Rate of BOD; Lo: ultimate BOD.

Based on observations showed that $k$ value of post aerated for 8 hours had higher than pre aerated (Table 1), which means that the rate of organic matter decomposition in the water has been aerated faster than before aeration. This is presumably due to the availability of oxygen obtained from the aeration process. Dhage et al. (2012) stated that the value of the rate of oxidation of organic matter $(k)$ for BOD is achieved is that the value of $k$ must be known for certain environmental conditions to evaluate the status of ultimate BOD appropriately.

The value of $k$ for pre aeration ranged from 0.1262 to 0.2776 per day and the value of $k$ for post aeration were from 0.2461 to 0.3335 per day while the value of $k$ for domestic sewage ranged from 0.1 to 0.6 per day (Dhage et al., 2012). While the value of $k$ for waste paper 
industries and sewage plants respectively 0.322 and 0.2224 per day (Abdelrosoul, 2001). Observations Thang et al. (2005) states that the average value of $k$ for which heavily polluted of lake by organic matter in Hanoi was 0.39 /day, and this indicates that the lake in Hanoi still has a good self- recovering ability. According Eckenfelder in Polli (1994), the value of $k$ for the polluted water is $0.1 /$ day. BOD values vary widely and are influenced by the rate reaction. Peavy et al. (1984) in Polli (1994) states that the value of $k$ determines the BOD reaction rate without affect the amount of the ultimate BOD. $k$ values pre and post aeration significantly different (ANOVA, $\mathrm{P}<0.1$ ), indicating that aeration can increase oxygen thus speeding up the oxidation reaction to decompose organic matter.

\section{Conclusion}

Aeration is an effort to improve oxygen waters to be able the need of oxygen for the microorganisms in the decomposition of organic matter. Pre aerated $\mathrm{BOD}_{5}$ is higher than post aeration. The rate of decomposition of organic matter $(k)$ has been aerated water is higher than before aeration. That is through aeration can improve the adequacy of oxygen resulting in oxygen for the microorganisms to decompose organic matter

\section{References}

Abdelrasoul, F. M. (2001). A comparative study of the bod rate constant of industrial waste water and sewage. Sixth International Water Technology Conference, IWTC, Alexandria, Egypt.

American Public Health Association. (APHA). (2005). Standard Methods for The Examination of Water and Waste Water Including Bottom Sediment and Sludges. 12-th ed Amer. Publ. Health Association Inc, New York.

Anwari, F., Muslim, G. R., Hadidan A., \& Mirwan, A. (2011). Studi penurunan BOD, COD, TSS dan pH limbah pabrik tahu menggunakan metode aerasi bertingkat. Prestasi, 1(1), 1-7.

Astono, W., M. S. Saeni., B. W. Lay dan S. Soemarto. (2008). Pengembangan model DO BOD dalam pengelolaan kualitas air Sungai Ciliwung. Forum Pascasarjana, 31(1), 37-45.

Cahyono, B. (2006). Budidaya ikan di perairan umum. Penerbit Kanisius, Yogyakarta.

Dhage, S. S., Dalvi, A. A., \& Prabhu, D. V. (2012). Reaction kinetics and validity of BOD test for domestic wastewater released in marine ecosystems. Environ Monit Assess, 184, 5301-5310. http://dx.doi.org/10.1007/s10661-011-2341-y

Endo, A., Srithongouthai, S., Nashiki, H., Teshiba, I., Iwasaki, T., Hama, D., \& Tsutsumi, H. (2008). DO-increasing effects of a microscopic bubble generating system in a fish farm. Marine Pollution Bulletin, 57, 78-85. http://dx.doi.org/10.1016/j.marpolbul.2007.10.014

Harsono, E. (2010). Evaluasi kemampuan pulih diri oksigen terlarut air Sungai Citarumhulu. Limnotek, 17(1), 17-36.

Polli., B. (1994). Kajian konsep pengukuran BOD sebagai indicator pendugaan pencemaran bahan organic di perairan daerah tropis. Disertasi. IPB, Bogor. 


\section{Macrothink

Qayyum, A., Ayub, M., \& Tabinda, A. B. (2005). Effect of Aeration on Water Quality, Fish Growth and Survival in Aquaculture Ponds. Pakistan J. Zool., 37(1), 75-80.

Romayanto, M. E. W., \& Wiryantodan Sajidan. (2006). Pengelolaan limbah domestik dengan aerasi dan penambahan bakteri Pseudomonas putida. Bioteknologi, 3(2), 42-49.

Santoso, B. (2010). Proses pengelolaaan air buangan industri tapioka. Jurnal Ilmiah Teknologi Dan Rekayasa, 15(3), 213-220.

Selvamuruga, M., Doraisamy, P., Maheswari, M., \& Nandakumar, N. B. (2010). Evaluation of Batch Aeration as a Post Treatment for Reducing the Pollution Load of Biomethanated Coffee Processing Waste Water. Global Journal of Environmental Research, 4(1), 31-33.

Singh, B. (2004). Determination of BOD kinetic parameters and evaluation of alternate methods. Thesis. Department Of Biotechnology \& Environmental Sciences. Thapar Institute of Engineering \& Technology.

Sulihingtyas, W. D., Suyasa, I. W. B. dan N. M., \& Wahyuni, I. (2010). Efektivitas sistem pengolahan instalasi pengolahan air limbah Suwung Denpasar terhadap kadar BOD, COD, dan amonia. Jurnal Kimia, 4(2), 141-148.

Thang, V. Q., Quan, P. V., Ha, B. T. T., \& Thuy, N. T. (2005). Evaluation of biodegradation rate constant $(k)$ and BOD pollution in the lake system of Hanoi. Annual Report of FY 2004, The Core University Program between Japan Society for the Promotion of Science (JSPS) and Vietnamese Academy of Science and Technology (VAST) : 115-119

Tchobanoglous, G., Burton, F. L., \& Stensel, H. D. (2003). Waste water engineering; Treatment and reuse (4th edition). Mc. Graw Hill.

\section{Copyright Disclaimer}

Copyright reserved by the author(s).

This article is an open-access article distributed under the terms and conditions of the Creative Commons Attribution license (http://creativecommons.org/licenses/by/3.0/). 